Farkhad Aliyev

ADA University

\title{
Political dimension of the second Karabakh war
}

tarting approximately from the dawn of new era and through early middle ages the region

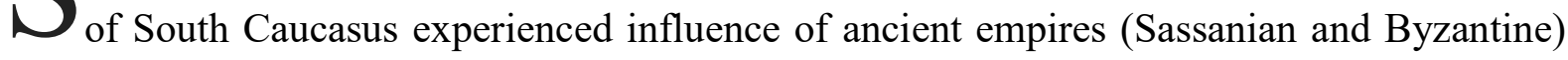
and Turkic tribes of Khazars, then followed by Arabs' conquests, after which until $19^{\text {th }}$ century this geographical area, known today as South Caucasus, was either controlled mainly by Iranian and Turkish ruling dynasties or experienced the Persian and Turkish military, political and cultural impact. Starting from $19^{\text {th }}$ century the region was conquered by Russian Empire, and since that time it had been included into the sphere of exclusive Russian military, political, economic and cultural influence.

The Karabakh problem (or Nagorno-Karabakh conflict between Azerbaijan and Armenia) in its contemporary form emerged approximately in the second half of the $19^{\text {th }}$ century when the discourse of nationalism came to the South Caucasus. Back then various ethnic groups which populated this region started to get occupied with conceptualization of their perceptions of what had to be considered 'theirs' in terms of territorial claims, historical 'truth', political expectations, traditions, etc. It was the period of so called initial 'nationbuilding' that took place in the framework of the Russian Empire, which, as was mentioned above, captured all these territories after victories in Russo-Turkish and Russo-Persian wars mainly in $18^{\text {th }}$ and $19^{\text {th }}$ centuries (even though the first conflicts between empires started back in the $17^{\text {th }}$ century).

It should be stressed specifically that the region of South Caucasus was historically extremely multi-ethnical, being a kind of 'melting pot' for various ethnic and religious groups. As an example, one can bring official results of the last Soviet census which took place in 1989. According to it, Armenians constituted 76,92\% of the population of Karabakh proper $^{393}$ while in Shusha (ancient city in Karabakh) Azerbaijanians constituted $92 \%$ of

\footnotetext{
${ }^{393}$ All-union Census 1989. Distribution of city and rural population of the Soviet republics' oblasts in terms of gender and nationality, Institute of Demography of the National Research University, "Higher School of Economics", za: http://www.demoscope.ru/weekly/ssp/resp_nac_89.php?reg=71
} 
population $^{394}$ from where all of them were expelled in 1992 as a result of Armenian forces' military operations. In general, throughout observable history ethnical distribution of population in this region was very mosaic and heterogenous.

In its contemporary form the conflict was 'unfrozen' in 1987-88s when Armenians of Karabakh Autonomous Oblast of the Azerbaijan Soviet Socialist Republic raised the issue of transfer of the Oblast from Soviet Azerbaijan to Soviet Armenia. This led to the first wave of Azerbaijanian refugees from Kafan (Armenia) in November of $1987^{395}$, then followed by tragedy in Sumgait (Azerbaijan) in February of 1988 and first wave of Armenian refugees from Azerbaijan. In autumn of 1991 (when the USSR did not already exist) full-scale military clashes in Karabakh began, which continued until May of 1994 when truce was signed. The war ended with defeat of Azerbaijan. Armenia captured not only Karabakh itself but also seven districts around Karabakh traditionally populated by Azerbaijanians. Thus, all the territories between Karabakh (surrounded by occupied seven districts) from one side and Armenia and Iran from another came under control of Armenian military forces. As a result, more than half of a million of Azerbaijanians had to leave their homes and became refugees: "roughly 40,000 from Nagorno-Karabakh and 560,000 from the surrounding seven occupied districts"396.

\section{Portents of war}

Since May 1994 the conflict was frozen, while parties thereto were busy with finding a peaceful solution to it in the framework of negotiations coordinated and led by Minsk group. Nevertheless, decades long negotiations did not produce any appreciable outcome. Azerbaijan insisted on necessity to obey the norms of international law and the UN Security Council's Resolutions Nos. 822 (April 30, 1993), 853 (July 29, 1993), 874 (October 14, 1993), 884 (November 12, 1993) obliging Armenia to withdraw its forces from seven occupied districts around Karabakh, while Armenia stayed firm in its intention to achieve the official international legal status for Karabakh and mainly kept the negotiations process running in circles.

\footnotetext{
${ }^{394}$ E. Amirbayov, Shusha's Pivotal Role in a Nagorno-Karabagh Settlement, [w:] Policy Brief, (red.) B. Shaffer, Cambridge 2001, s. 2.

${ }^{395}$ T. de Waal, Black garden: Armenia and Azerbaijan through peace and war, New-York 2003, s.18-19.

${ }^{396}$ Human rights situation of internally displaced persons in Azerbaijan, Human Rights for All, za: https://www.humanrightsclub.net/en/news/2019/human-rights-situation-of-internally-displaced-persons-inazerbaijan/ (19.09.2019), zob. także: Global Report on Internal Displacement, Internal Displacement Monitoring Center \& Norwegian Refugee Council, May 2017, https://www.internal-displacement.org/globalreport/grid2017/\#download, s. 113.
} 
Despite some bleak hopes which appeared after coming to power in 2018 of the current Armenian Prime-minister Nikol Pashinyan, who was not connected with previous Armenian leadership, majority of which was involved into the first Karabakh war (some of them were 'warlords' back then), and at first seemed to present himself as a bearer of new ideas and approaches, nevertheless, all that followed dispelled such illusions and expectations.

Armenian society (as well as Azerbaijanian one) had always been extremely sensitive to everything related to Karabakh. Moreover, for both Armenian and Azerbaijan societies the Karabakh itself traditionally had been a very significant part of national mythology. And any attempts to revise, at least a little bit, Armenia's approaches to negotiations and to 'soften' even slightly its positions were perceived by the society as 'betrayal of national interests' (to be fair situation was the same with Azerbaijan).

All that followed allows to suggest that Prime minister Nikol Pashinyan could not change the public opinion of the Armenian society and to stand firmly against the most aggressive groups of the latter which always promoted only the idea of 'no-concessions', thus actually derailing the peace talks during more than twenty years.

Being unable to change the attitude of the general public in Armenia Prime minister Nikol Pashinyan in his moves and rhetoric had become even more assertive, adamant and to a certain extent aggressive if compared to his predecessors. Subsequent actions and declarations which were taken and made by Armenian leadership had finally led almost thirty years long negotiations process to the deadlock.

On March 31, 2019 Davit Tonoyan, at that time the Minister of defense of the Republic of Armenia, during the meeting with the representatives of Armenian community in New York, in the framework of his visit to the USA, "openly rebuked the Azerbaijani side's zero-sum 'land for peace' formula for conflict resolution, in which a bilateral settlement would require that the Armenian side first make territorial concessions to Azerbaijan. Instead, he called on Armenia to prepare to pursue new war for new territories" ${ }^{397}$. The formula of 'land for peace' since the beginning of negotiations in 1994 was considered a kind of a cornerstone for the process of finding a peaceful resolution to the conflict, meaning that Armenia could receive Azerbaijan's consent for Karabakh to get official legal status (highest possible autonomy within Azerbaijan) in exchange for deoccupation of territories: seven districts around Karabakh, recognized by all the international

\footnotetext{
${ }^{397}$ E. Abrahamyan, Rationalizing the Tonoyan Doctrine: Armenia's Active Deterrence Strategy, Eurasia Daily Monitor (Volume 16 Issue 64), May 2, 2019. za: https://jamestown.org/program/rationalizing-the-tonoyandoctrine-armenias-active-deterrence-strategy/ (22.05.2020)
} 
community according to norms and principles of international law - together with Karabakh itself - as the territories of the Republic of Azerbaijan, that were occupied by Armenia at the beginning of 90 s of the last century.

The whole incident was later even more aggravated by the position of the Prime minister Nikol Pashinyan, who backed his defense minister: "If Davit Tonoyan had made a different statement I would have dismissed him as defense minister. What did the defense minister say? He said that if a war breaks out our objective will be to win that war" 398 .

The reaction of the Azerbaijan was obvious and predictable: "the Azerbaijani Foreign Ministry condemned the "provocative" statement, saying that it undermined international efforts to resolve the Karabakh conflict" $" 399$.

Later in May of 2019 Prime-minister Pashinyan made one more provocative 'gesture' publicly joining national Armenian dances in Shusha, commemorated to so called 'liberation' of the latter by Armenians on May 9, $1992^{400}$. This episode of the first Karabakh war was one of the most tragic ones in a long line of that time calamities and losses Azerbaijanians had to pass through at the beginning of 90 s of the last century. Moreover, Shusha had been traditionally accepted by Azerbaijanians as a cradle of their culture.

One year later, as if wishing to worsen situation even more, on 21 May 2020 "an 'inauguration ceremony' was organized in Shusha for the puppet leader of the 'NagornoKarabakh Republic', an unrecognized entity on Azerbaijan`s territories currently occupied by Armenia. While the continuing occupation and the fruitless negotiations that have been lingering for over twenty five years already, are a constant source of frustration for the Azerbaijani society, this year's provocative move by the Armenian side brought this frustration to what may seem as all-time high" 401 .

Needless to say, that such absolutely inappropriate, in the context of ongoing back then peace talks, actions of Armenian leadership provoked obvious very negative reaction in Azerbaijan society, resurrecting in memories of not only more than half of a million refugees

\footnotetext{
398 Pashinyan Backs Defense Chief's Tough Talk On Karabakh in The Armenian Mirror-Spectator, April 2, 2019, za: https://mirrorspectator.com/2019/04/02/pashinyan-backs-defense-chiefs-tough-talk-on-karabakh/ $(15.05 .2020)$

${ }^{399}$ Ibidem.

400 Armenian PM joins folk dance in Karabakh's Shushi, News.am, 9 May 2019, za: https://news.am/eng/news/511784.html (15.05.2020)

${ }^{401}$ Huseynov R., Shusha provocation: a fatal blow to the peace process?, Topchubashov Center, za: https://topcenter.org/en/analytics/3022/shusha-provocation-a-fatal-blow-to-the-peace-process (22.05.2020)
} 
but the whole Azerbaijan society the episodes of national humiliation at the beginning of 90s of the $20^{\text {th }}$ century.

All these provocative or probably ill-conceived actions and declarations on behalf of the leadership of the country with which negotiations for peaceful resolution of the conflict back then had been already taking place for more than two decades to no avail - in the context of overall slipping of peace talks at that time - could not have more negative effect on general perception by the Azerbaijan of the further 'prospects' of such 'negotiations'.

\section{Forty-four days of war}

Irregular sporadic local clashes between military forces of two countries had been taking place throughout all the years of negotiations after 1994. Nevertheless, as a rule such clashes had always taken form of occasional shootings continued for several hours at maximum. The longest escalation happened in April of 2016 when confrontation had taken form of relatively wide scale military operations conducted by armies of the two countries during four days, after which Azerbaijan claimed to return under its control some territories which previously were occupied by Armenia. As Thomas De Waal put it, "the April fighting was the worst outbreak of violence since 1994. But it was not a full-scale military offensive by Azerbaijan, which has periodically said it does not rule out the use of force to reconquer territory it lost in the conflict in the 1990s. More likely, it was a limited operation staged by Baku to shake the status quo, put the conflict back on the international agenda, and put the Armenian side under pressure. The Azerbaijani army recovered two hills, one of which, Lele Tepe, lies about 3 miles north of the Iranian border and has some strategic significance" ${ }^{„ 402}$.

In general, the expert community was almost unanimous in understanding of the reasons and purposes of this - the most wide-scale at that time - aggravation of the situation: "a carefully controlled escalation served to raise international awareness of the fragility of a status quo which Azerbaijan regards as unfavourable, in order to galvanize the international mediators and put pressure on Yerevan to be constructive at the negotiating table. In addition, the military escalation also destroyed any expectations Armenia might have harboured for support from the Russian-led Collective Security Treaty Organization (CSTO).

\footnotetext{
${ }^{402}$ T. de Waal, Prisoners of the Caucasus: Resolving the Karabakh Security Dilemma, June 16, 2016, Carnegie Europe, za: https://carnegieeurope.eu/2016/06/16/prisoners-of-caucasus-resolving-karabakh-securitydilemma/j1yq (22.05.2020).
} 
Its response was fragmented, with Belarus, for example, openly supporting Azerbaijan's territorial integrity" ${ }^{\prime \prime}$.

The second Karabakh war between Azerbaijan and Armenia, its consequences and expectations after it, cannot be scrutinized without understanding of interests and positions of key actors involved in different forms into the political processes in South Caucasus: European countries, Iran, Russia, Turkey, USA. All the above-mentioned centers of power tried to be very active in the region after the collapse of the USSR in the framework of negotiations and direct involvement in the framework of bilateral relations with the three countries of the region.

Three out of five above-listed international actors involved - Iran, Russia, Turkey always had and still have quite a specific role due to their historical and cultural influence in this region.

Iran, if compared to other international actors involved, has probably been the less active during the negotiations process. Below are some of the reasons of Iran's 'diminished' direct participation in it:

- Iran's own very difficult overall political and economic situation due to decades long American sanctions against it,

- Very mixed (often negative) perception of Iran in Azerbaijanian society due to Iran's decades long constant political, economic and trade relations with Armenia,

- Extremely cautious attitude of Iranian leadership to Azerbaijan in general due to the fact that more than 20 millions of ethnic Azerbaijanians live in Iran, being often involved into various anti-governmental protests.

Despite the above-mentioned, Iran, nevertheless, also tried from time to time to raise the level of its own engagement into the process of conflict's resolution. The last such attempt took place during the second Karabakh war, when Iran suggested its plan of ending the military operations and post-war resolution with its official special representative travelling to Azerbaijan, Armenia and Russia. Even though this endeavor did not give any results it was an indicator of Iran's willingness to play more active role in the region, especially in light of rapidly changing back then situation, when the status-que (which existed for almost 30 years) had been turned upside down by Azerbaijan's victories on the battle-field, thus

\footnotetext{
${ }^{403}$ Z. Shiriyev, Violence in Nagorny Karabakh a reflection of Azerbaijan's Security Dilemma, 22 April 2016, Chatham House, za: https://www.chathamhouse.org/2016/04/violence-nagorny-karabakh-reflection-azerbaijanssecurity-dilemma (22.05.2020).
} 
threatening Iran to find itself outside the forthcoming geopolitical architecture of the region with absolutely new realities after Armenia's defeat and Azerbaijan's victory.

USA, Russia and France are the co-chairs of the Minsk group, while Turkey is a member of the latter and the major strategic ally and neighbor of Azerbaijan (two nations has centuries long historical connections and ties). Turkey also has very close relations not only with Azerbaijan but also with Georgia (another neighbor of Azerbaijan and Armenia in the South Caucasus), thus balancing to a certain extent very significant Russian influence in the region.

As it was mentioned above, after North and South Caucasus were captured by the Russian Empire in $19^{\text {th }}$ century, this region until now has traditionally been considered as a sphere of exclusive influence of Russia and the latter still is very sensitive to any attempts of third parties to intervene thereto. Nevertheless, after disintegration of the Soviet Union situation albeit slowly had started to change steadily.

Considering the following, together with the outcomes of the forty-four days long war, one can suggest that some kind of non-official 'agreements' and/or 'negotiations' could have taken place beforehand between Azerbaijan and Turkey from one side and Russia from another:

- endless but futile attempts of Armenia to have Russia directly involved into the war;

- Russia's quite 'passive' position (compared to the one it could actually have, especially considering Russia's military potential and influence in the region) as an Armenia's ally; even though during the war quite often divergent information appeared in different sources about covert supplies of military equipment and weapons from Russia to Armenia, including those from Russian military base in Armenia and from Russia itself, the latter did not intervene into the conflict directly and always during the course of the conflict stressed the difference between (i) the threat to Armenia as an ally of Russia and (ii) military operations in Karabakh and seven districts surrounding it (indirectly and sometimes directly pointing out that those are the territories of the Republic of Azerbaijan according to the international law, but not of the Republic of Armenia); such declarations and official position of Russian government signaled to Armenia that the latter itself is not under attack to have Russian military involvement and everything that was happening back then was taking place on the internationally recognized territory of the Republic of Azerbaijan (not Armenian territory); 
- openly belligerent declarations and actions of Turkey, which had always rendered full support to Azerbaijan in all spheres after the collapse of the USSR.

Also, in light of the situation which preceded the beginning of war, the following factors should be considered seriously:

1) Russia's discontent with politics of the Pashinyan's government since 2018 and probably its intentions to remove him from office or run him off as a political leader in some other ways. It is a well-known fact that Russian political leadership has always been very cautious and vigilant towards post-soviet leaders which came to power as a result of fight against local corrupted regimes (which as a rule always had and still have quite close ties with Russian political and financial elites), and the same happened in Armenia in 2018.

2) Growing dissatisfaction of Azerbaijan with the officially 'neutral' but often seemed 'pro-Armenian' position of Minsk Group's co-chairs in the process of finding the peaceful resolution, which led to increased diplomatic pressure from Azerbaijan during last years on the co-chairs of Minsk Group and first of all on Russia as a key player in the region in the context of negotiations. The relatively recent prime example of such not so 'neutral' approach of Mins Group's co-chairs to the position of Azerbaijan was the fact that when the UN General Assembly's Resolution 62/243 was adopted on 25 April 2008 by the votes of 39 countries, 7 countries voted against this resolution, including obviously Armenia itself but also Russia, USA and France (all the co-chairs of Minsk Group). This resolution did not even have a binding character and simply re-affirmed "continued respect and support for the sovereignty and territorial integrity" of Azerbaijan "within its internationally recognized borders", demanded the "immediate, complete and unconditional withdrawal of all Armenian forces from all the occupied territories of Azerbaijan", and emphasized that "no state shall render aid or assistance" to maintain the occupation of Azerbaijani territories" [see: UN General Assembly's Resolution 62/243]. In addition to the above-mentioned, below are listed a few other reasons explaining such extremely skeptical attitude of Azerbaijan to the process of negotiations and its general dissatisfaction with the course of events back then:

- continuing delays in the negotiations and absence of really tangible (even initial) outcomes during almost 30 years, 
- quite passive (or probably absence of) 'pressure' of the co-chairs - Russia, US and France on Armenia - in terms of necessity for Armenia to at least start to follow the requirements of international law and four Resolutions of the UN Security Council adopted back in 1993, and to set in motion the phase of substantive negotiations instead of just endless 'table-talks' year after year without any notable results and contours of the forthcoming real peace resolution,

- provocative or ill-conceived actions and declarations of Armenian leadership which were mentioned above.

3) Turkey's pressure on Russia, including political and military ones in Syria, Libya, Middle East in general and South Caucasus, including growing economic connections between Turkey and Georgia and decades long economic blockade of Armenia by Turkey in support of Azerbaijan.

This factor should be considered in the wider context of worsening of overall situation for and in Russia itself: (i) Western sanctions against Russia since 2014 because of annexation of Crimea and 'hybrid war' against Ukraine, (ii) pressure and threat of new sanctions because of Russia's position in the events in Belarus in 2020, (iii) pressure on Russia and threat back then of sanctions because of involvement of Russia's political leadership into poisoning of one of the Russian opposition's leaders Alexey Navalny with his subsequent imprisonment and violent suppression of mass protests in his support in 2020-21, (iv) economic stagnation and overall serious worsening of economic situation in Russia as a result of Western sanctions since 2014.

Therefore, growing Turkish influence and pressure in the regions of Russian involvement together with the above-listed Russia's own internal problems and significant deterioration of Russia's positions on international arena made it to reconsider seriously its overall attitudes, approaches and potential of influence not only in the Middle East but also in South Caucasus.

4) Certain compatibility of intentions and interests of both Turkey and Russia in becoming key 'peace-makers' in South Caucasus thus 'squeezing' out the US and European powers from here.

5) Many similarities in mentality and ways of thinking and approaches to the process of problem-solving (in a wider sense) between political elites of Turkey, Russia and Azerbaijan, if compared with quite significant (at least by now) differences with those 
of the political elites in the US and European countries. This factor cannot be underestimated in view of how fast certain parties can understand each other and to achieve certain agreements (it is almost similar to speaking the same 'language').

6) Obvious partial and temporary 'disengagement' of the USA from the regional processes in light of the events which were taking place there on the eve of the US 2020 Presidential elections. This factor should not be underestimated because the US still remains the only objectively powerful actor able to promote its own position against the one of traditionally influential in this region Russia. Considering the above-mentioned relatively 'diminished' possibilities of Iran in the process of finding peaceful resolution, it should be pointed out that unfortunately European countries still are not able to 'play' in the region 'on par' with Russia.

Thus, one can list the following consequences of the developments and factors considered above:

- temporary reduction of the US involvement into the regional affairs in the context of overall more 'weak' position of European actors in the region,

- obvious worsening of domestic (political and economic) situation in Russia together with serious ongoing crisis in Russia's relations with the Western countries and their sanctions against it,

- significantly growing influence of Turkey in the region and its above-mentioned pressure on Russia in different regions of the world,

- Russia's intention to keep others away from the region (it simply had to accept the new position and increased status of Turkey due to the above-mentioned objective circumstances).

\section{Consequences and outcomes}

Summing up and proceeding from the aforementioned, one can conclude that Azerbaijan political leadership, having full and constant support from Turkey, has chosen the right moment more than accurately and properly to change the status quo that existed for almost 30 years until October 2020 .

As a result of forty-four days long effective military operations the following was achieved by Azerbaijan:

- complete turning of the previous 'status-quo' in Karabakh problem's resolution upside down, 
- significant transformation of the strategic balance of powers in the South Caucasus,

- establishment of absolutely new geopolitical realities in the region,

- certain diminishing of European actors' influence in the Azerbaijan and to a certain extent in wider South Caucasus (at least temporary),

- critical and never seen before growth of strategic influence of Turkey in the South Caucasus (since $19^{\text {th }}$ century, as it was mentioned before, Russia traditionally had considered this region as its own 'back-yard', keeping 'third parties' away, first of all, Turkey that for centuries was an active actor in this region before $19^{\text {th }}$ century,

- start of diminishing of Russian influence in the South Caucasus due (i) to return of Turkey thereto and (ii) possible perspectives of reconsideration by Armenia of its 'strategic partnership' with Russia and Armenia's slow drifting towards the West (in light of ongoing mostly negative dynamics in Russo-Georgian relations).

Summing up all the above analysis herein, one should point out that Azerbaijan during forty-four days of military operations could ensure implementation of all four Resolutions of the UN Security Council adopted back in 1993 (unfortunately this has not been done during almost thirty years of futile negotiations, meetings and talks). Nevertheless, it should also be pointed out specifically that majority of these results could have been achieved much earlier and without human losses if only the Armenian leadership would be more decisive in following the norms of international law and ready to have real negotiations, and co-chairs of the Minsk Group would be more assertive in persuasion of Armenia to do so.

\section{Streszczenie}

Artykuł dotyczy analizy politycznego wymiaru niedawnej wojny w Karabachu (uwarunkowania, procesy polityczne konfliktu, jego historia, konsekwencje). Artykuł zawiera również wstępne informacje o przesłankach historycznych i tle tego prawie stuletniego konfliktu na Kaukazie Południowym. W artykule dodatkowo przeanalizowano polityczne skutki drugiej wojny karabaskiej wraz z możliwymi konsekwencjami.

\section{Słowa kluczowe:}

Armenia, Azerbejdżan, konflikt karabachski, spór terytorialny między Armenią a Azerbejdżanem

\section{Key words:}

Armenia, Azerbaijan, Karabakh conflict, Territorial dispute between Armenia and Azerbaijan. 


\section{Bibliografia:}

1. Abrahamyan E., Rationalizing the Tonoyan Doctrine: Armenia's Active Deterrence Strategy, Eurasia Daily Monitor (Volume 16 Issue 64), May 2, 2019. https://jamestown.org/program/rationalizing-the-tonoyan-doctrine-armenias-activedeterrence-strategy/

2. All-union Census 1989. Distribution of city and rural population of the Soviet republics' oblasts in terms of gender and nationality, Institute of Demography of the National Research University, "Higher School of Economics", http://www.demoscope.ru/weekly/ssp/resp_nac_89.php?reg=71

3. Amirbayov E., Shusha's Pivotal Role in a Nagorno-Karabagh Settlement, [w:] „Policy Brief”, B. Shaffer (red.), Cambridge 2001,

4. Armenian Minister of Defence warns: "New war-new territories", March 31, 2019, https://regnum.ru/news/polit/2602031.html

5. Armenian PM joins folk dance in Karabakh's Shushi, News.am, 9 May 2019, https://news.am/eng/news/511784.html

6. Global Report on Internal Displacement, Internal Displacement Monitoring Center \& Norwegian Refugee Council, May 2017, p. 113, https://www.internaldisplacement.org/global-report/grid2017/\#download

7. Human rights situation of internally displaced persons in Azerbaijan, Human Rights for All, June 19, 2019, https://www.humanrightsclub.net/en/news/2019/human-rightssituation-of-internally-displaced-persons-in-azerbaijan/

8. Huseynov, Rusif, Shusha provocation: a fatal blow to the peace process?, Topchubashov Center, 22 May 2020, https://top-center.org/en/analytics/3022/shushaprovocation-a-fatal-blow-to-the-peace-process

9. Pashinyan Backs Defense Chief's Tough Talk On Karabakh in The Armenian MirrorSpectator, April 2, 2019, https://mirrorspectator.com/2019/04/02/pashinyan-backsdefense-chiefs-tough-talk-on-karabakh/

10. Shiriyev, Z., Violence in Nagorny Karabakh a reflection of Azerbaijan's Security Dilemma, 22 April 2016, Chatham House, https://www.chathamhouse.org/2016/04/violence-nagorny-karabakh-reflectionazerbaijans-security-dilemma

11. de Waal, T. Black garden: Armenia and Azerbaijan through peace and war, NewYork University Press 2003, 337 pp.

12. de Waal, T. Prisoners of the Caucasus: Resolving the Karabakh Security Dilemma, June 16, 2016, Carnegie Europe, https://carnegieeurope.eu/2016/06/16/prisoners-ofcaucasus-resolving-karabakh-security-dilemma/j1yq

13. UN General Assembly's Resolution 62/243 dated 25 April 2008, https://undocs.org/A/RES/62 